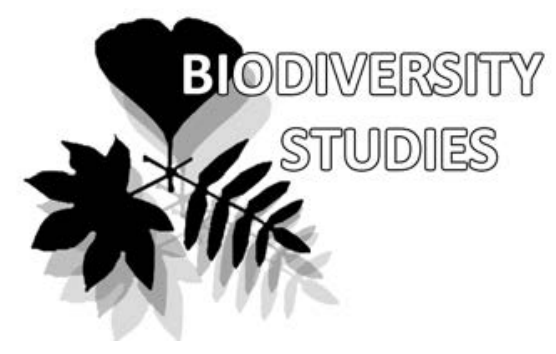

\title{
Findings to the flora of Russia and adjacent countries: New national and regional vascular plant records, 1
}

\author{
Alla V. Verkhozina*1, Viktor N. Belous ${ }^{2}$, Olga A. Chernysheva ${ }^{1}$, \\ Alexandr L. Ebel ${ }^{3}$, Andrey S. Erst ${ }^{4}$, Nikolai V. Friesen ${ }^{5,6}$, Mariya A. \\ Iuzhakova ${ }^{7}$, Alexander A. Kuznetsov ${ }^{3}$, Alexander N. Luferov ${ }^{5}$, \\ Vladislav V. Murashko ${ }^{1}$, Ramazan A. Murtazaliev ${ }^{8,9}$, Svetlana V. \\ Ovchinnikova $^{4}$, Wei Wang ${ }^{10}$, Olga Yu. Zavgorodnyaya ${ }^{11,12}$, Andrey \\ Yu. Korolyuk ${ }^{4}$, Stepan A. Senator ${ }^{13}$, Evgenii G. Zibzeev ${ }^{4}$, Vladimir M. \\ Vasjukov $^{13}$ \& Denis A. Krivenko ${ }^{1,3,11}$,
}

\begin{abstract}
${ }^{1}$ Siberian Institute of Plant Physiology and Biochemistry SB RAS, Irkutsk, Russia

${ }^{2}$ North-Caucasus Federal University, Stavropol, Russia

${ }^{3}$ National Research Tomsk State University, Tomsk, Russia

${ }^{4}$ Central Siberian Botanical Garden SB RAS, Novosibirsk, Russia

${ }^{5}$ I.M. Sechenov First Moscow State Medical University, Moscow, Russia

${ }^{6}$ Botanical Garden of the Osnabrueck University, Osnabrueck, Germany

${ }^{7}$ National Tomsk Polytechnic University, Tomsk, Russia

${ }^{8}$ Mountain Botanical Garden, DSC RAS, Makhachkala, Russia

${ }^{9}$ Dagestan State Medical University, Makhachkala, Russia

${ }^{10}$ Institute of Botany CAS, Beijing, China

${ }^{11}$ Western Baikal Protected Areas, Irkutsk, Russia

${ }^{12}$ Irkutsk State University, Irkutsk, Russia

${ }^{13}$ Institute of Ecology of the Volga River Basin RAS, Tolyatti, Russia
\end{abstract}

* corresponding author, allaverh@list.ru

Manuscript received: 03.04.2019

Review completed: 02.05.2019

Accepted for publication: 06.05.2019

Published online: 08.05.2019

\begin{abstract}
A B S T R A C T
For the first time, new locality of Viola suavis is recorded for the Asian part of Russia, Chloris virgata, $\times$ Elyhordeum arcuatum and Persicaria orientalis for Siberia, Thalictrum amurense for Japan, Eritrichium pseudolatifolium and E. pseudostrictum for Kirghizia, Aquilegia jucunda, A. vulgaris and Viola birta for Baikal Siberia, Astragalus pallescens and A.physodes for the North Caucasus, Astragalus guttatus for the Central Caucasus, Astragalus somcheticus, Lotus frondosus and Vicia bithynica for Dagestan, Medicago $\times$ varia and Lappula tuvinica for the Irkutsk region. For each species, the general distribution, habitat, and taxonomy, indicating differences from related species and location are presented.
\end{abstract}

Ke y w o rd s : floristic findings, taxonomy, Asian Russia, Caucasus, Japan, Kyrgyzia, Mongolia

\section{P E 3 Ю M E}

Верхозина А.В., Белоус В.Н., Чернышева О.А., Эбель А.А., Эрст А.С., Фризен Н.В., Южакова М.А., Кузнецов А.А., Ауферов А.Н., Мурашко В.В., Муртазалиев Р.А., Овчинникова С.В., Ванг В., Завгородняя О.Ю., Королюк А.Ю., Сенатор С.А., Зибзеев Е.Г., Васюков В.М., Кривенко А.А. Находки во фморе России и сопредельных стран: новые национальные и региональные мокалитеты сосудистых растений, 1. Впервые Аля Азиатской части России приводится Viola suavis, Аля Сибири - Chloris virgata, $\times$ Elyhordeum arcuatum, Persicaria orientalis, Аля Японии Thalictrum amurense, Аля Киргизии - Eritrichium psendolatifolium, E. psendostrictum, Аля Байкальской Сибири - Aquilegia jucunda, A. vulgaris, Viola hirta, Аля Северного Кавказа - Astragalus pallescens, A. physodes, А^я Центрального Предкавказья - Astragalus guttatus), Аля Аагестана - Astragalus somcheticus, Lotus frondosus, Vicia bithynica, Аля Иркутской области Medicago × varia, Lappula tuvinica. А^я кажАого вила представ ены общее распространение, местообитания, таксономия с указанием отАичий от близких виАов и местонахожАения.

КАючевые слова: флористические находки, таксономия, Азиатская Россия, Кавказ, Киргизия, Япония, Монголия
With this paper we introduce a new annual series, the main purpose of which is to make significant floristic findings from Russia and neighboring countries more visible in Russia and abroad. This paper was prepared by the team united more by scientific cooperation than the taxonomy or geography of the species. In total, this paper presents new records for 18 vascular plant species from 3 Eurasian countries, obtained during field explorations, as well as during taxonomic revisions of herbarium materials.

\section{Aquilegia jucunda Fisch. \& Avé-Lall. (Ranunculaceae)}

Contributors: Andrey S. Erst \& Mariya A. Iuzhakova

Distribution and habitat

A. jucunda is a species naturally distributed in RUSSIA (Altai Territory, Krasnoyarsk Territory, Zabaikalsky Ter- ritory, Irkutsk Province, Altai Republic, Buryatia Republic, Tyva Republic, Khakassia Republic, Yakutia Republic), CHINA (Xinjiang), KAZAKHSTAN (Almaty and East Kazakhstan Province) (Erst et al. 2016). It resides anywhere from forest to subalpine and alpine, mainly on mixed grass, grass-sedge and sedge meadows, often on stony substrate and fine ground. This paper for the first time indicates the distribution of $A$. jucunda for the most eastern part of its range in Transbaicalia.

\section{Taxonomic notes}

A. jucunda was described by F.E.L. Fischer and R. AvéLalleman in "Index Seminum, quae Hortus Botanicus Imperialis Petropolitanus pro Mutua Commutatione Offert. Accedunt Animadversiones Botanicae Nonnullae", however, without indication of its distribution and habitat. The comparative characteristics of this species with other closely related taxa were also not given. A. jucunda is often 


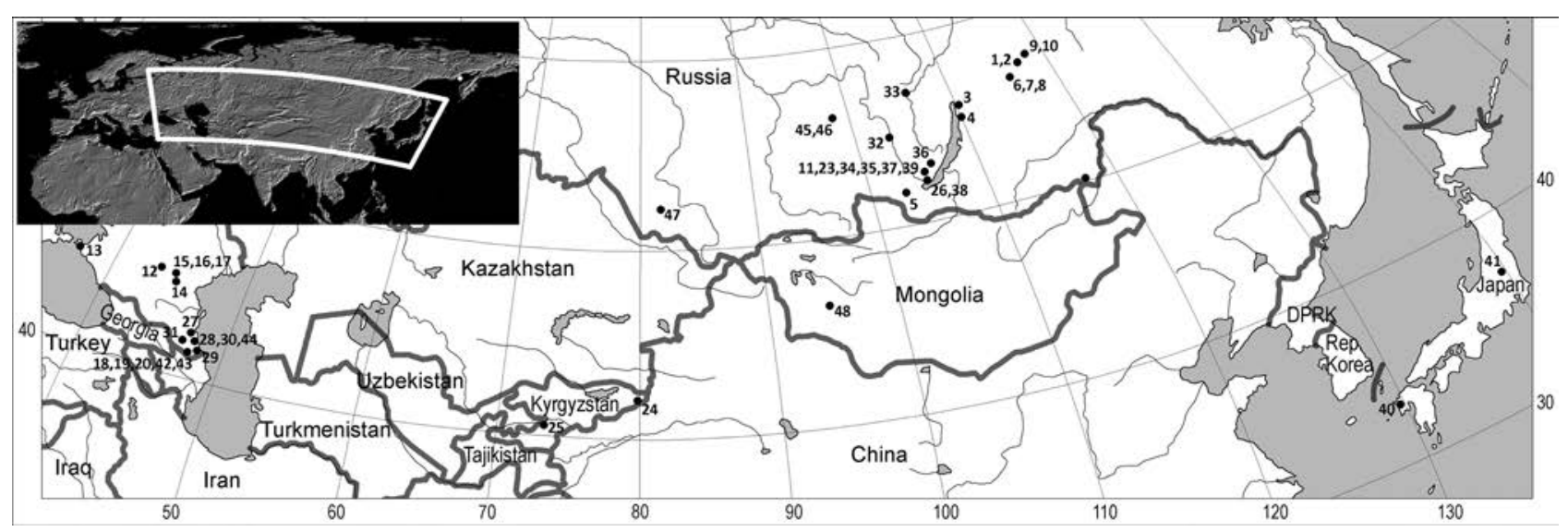

Figure 1 Locations of new findings (see the bolded numbers in the test)

referred to as a synonym of $A$. glandulosa Fisch. ex Link. Further C.F. Ledebour (1843) in his fundamental work "Flora of the Russian Empire" pointed out the following differences of $A$. glandulosa from $A$. jucunda: leaf blades rounded (in $A$. glandulosa - pointed); the filaments at the beginning of flowering are erect parallel (in $A$. glandulosa diverging); fruits are ovoid, scarred at the base (A. glandulosa - pi-shaped, constricted at the base); sepals ovate (in $A$. glandulosa - obovate); petals obovate, pale yellow, on each side, (A. glandulosa - wedge-shaped oblong, obtuse at the top, acuminate above, violet-blue, rarely white, almost completely separated from each other); narrowly oval anthers (linear in A. glandulosa); pistils 6-10 (in A. glandulosa-8-15). Seeds longitudinally almost 5-fin (in $A$. glandulosa - fine-grained 3-fin). In later reports, $A$. jucunda is synonymous with $A$. glandulosa (Bulavkina 1937, Munz 1946, Vasilyeva 1992, Friesen 1993). Both species are described from Altai and Kazakhstan. Our data confirm the distinctness of $A$. glandulosa and $A$. jucunda (Erst \& Vaulin 2014). We believe that A. jucunda should be recognized as an independent taxon based on the following characters: bicoloured petals (white-blue or whitening at the end of the limb of the petals and blue spur) that are parallel to each other, not spatially separated, angled and not overlapping limb petals and longer, curved at the end of the spur. R. Nold in his monograph "Columbines: Aquilegia, Paraquilegia and Semiaquilegia also point to the isolation of these taxa (Nold 2003).

\section{Examined specimens (new records)}

RUSSIA: Irkutsk Province, № 1210, m. 168, coll. Preobrazhensky (MW0092978): 1; Irkutsk Province, Nizhnyaya Sygykty River, $1750 \mathrm{~m}$ a.s.l., 09.08.1958, coll. Preobrazhensky (MW0092982): 2; Buryatia Republic, Stanovoye Nagorye, Ilbikaichi River, a tributary of the Tompuda River, gravelly mountain slope, $1900 \mathrm{~m}$ a.s.l., 07.22.1966, coll. L. Malyshev, E. Titov (IRK): 3; Buryatia Republic, the Kurumkansky District, the Barguzinsky Range, basin of the Alla River, $1825 \mathrm{~m}$, point 5, alpine meadow, 07.19.2014, coll. A.A. Taran (IRK): 4; Buryatia Republic, Eastern Sayan, Tunkinsky Alps, the Tubota River, in the alpine belt, $1800 \mathrm{~m}$ a.s.l., on the stony slope, 23.07.1963, coll. L.I. Malyshev (NSK): 5; Buryatia Republic, Stanovoe highlands, South Muisky ridge, upper reaches of the Kindikan river, in the subalpine belt, on a meadow slope, 25.07.1965, № 280, coll. Yu. Petrochenko (NSK): 6; Stanovoe highlands, South Muisky ridge, the river to the east of the Akundakan brook, in the subalpine belt, $1600 \mathrm{~m}$ a.s.l., subalpine sedge meadow in place of newly melted snow, 3.08.1966, № 761, coll. M. Ivanova, O. Volchugov (NSK): 7; Buryatia Republic, Stanovoe highlands, South Muisky ridge, the river to the east of the Akundakan brook, in the subalpine belt, $1700 \mathrm{~m}$ a.s.l., at the bottom of the crumbling slope of the trough, 03.08.1966, № 1539, coll. M. Ivanova, O. Volchugov (NSK): 8; Zabaikalsky Territory, Stanovoe highlands, Kodar ridge, upper reaches of the Apsat river, in the forest belt, height $1300 \mathrm{~m}$ a.s.l., on the river pebbles, 10.07.1964, №. 255, coll. L. Malyshev, Yu. Petrochenko (NSK): 9; Zabaikalsky Territory, Stanovoe highlands, Kodar ridge, upper reaches of the Apsat river, in the subalpine belt, $1550 \mathrm{~m}$ a.s.l., on a grassy meadow, 16.07.1964, № 598, coll. L. Malyshev, Yu. Petrochenko (NSK): 10.

\section{Aquilegia vulgaris L. (Ranunculaceae)}

Contributors: Denis A. Krivenko \& Alexander A. Kuznetsov Distribution and habitat

A. vulgaris (European columbine, Common columbine, Granny's nightcap, Granny's bonnet) is a species with natural distribution in Central and Northern Europe, British Isles, northern and middle Balkan countries, North of the Italian and Iberian Peninsulas (Munz 1954). The species is cultivated as an ornamental plant in numerous countries outside Europe, where it has become naturalized, e.g. Macronesia, Asores, the Americas, Oceania, Russia. This species grows in the forest edges, shady places, meadows, roadsides, and banks of rivers and streams; altitudes $50-1200 \mathrm{~m}$. The species is sporadically distributed in Siberia, where it tends to concentrate along the valley bottoms near towns and villages and grows wherever conditions are suitable, not far from the places of original cultivation (Nardi 2015). Hybrids morphologically similar to $A$. vulgaris can be found near natural populations of $A$. sibirica Lam.

\section{Taxonomic notes}

More than 50 subspecies and related species have been described from Europe. The plants grow anywhere from 30 to $100 \mathrm{~cm}$ or more, with inflorescence hairy, sometimes glandular-hairy above. The basal leaves are biternate, the leaflets glabrous above and pilose beneath. The flowers, in various shades of purple, blue, pink and white, are pendent or horizontal with hooked spurs. The sepals are spreading, ovate-lanceolate (Nold 2003). The stamens short and not exerted or equal to petal lamina. Aquilegia vulgaris is morphologically similar to $A$. ophiolitica Barberis \& Nardi in short exerted staminal column, homogeneous corolla and isotropic petals; however, it distinctly differs from $A$. ophiolitica by the absence of glands in the basal part of the plant, frondose inflorescence, spathulate petal lamina and 0 -exserted or exent of 1-2 mm petal lamina (Nardi 2015).

\section{Examined specimens (new records)}

RUSSIA:Irkutsk Province, Irkutsk city, Akademgorodok, territory of SIPPB SB RAS, 52 $14^{\prime} 21.02^{\prime \prime N}, 104^{\circ} 16^{\prime} 20.83^{\prime \prime E}$, 
arboretum, 23.06.2017, coll. D.A. Krivenko 48121, 48122 (IRK), 48123 (MW), 48124, 48125 (NS): 11.

\section{Astragalus guttatus Banks \& Sol. (Fabaceae)}

\section{Contributor: Victor N. Belous}

\section{Distribution and habitat}

Geographical distribution: Iranian-Turanian. From the territory of the former USSR the species (under the name A. striatellus Pall. ex M. Bieb.) is found in Transcaucasia, Middle Asia, Crimea and Eastern Caucasus also: "Dagestan" (Podlech \& Zarre 2013).

It was first found in the territory of the Central Ciscaucasia: the Southern Primanychye and the Prikumsk highlands (Belous 2006). The ecologo-coenotical optimum of the species is associated with the subzonal belt of grassland (Festuca valesiaca) and desert steppes for Ciscaucasia's plain and lowland landscapes. This taxon is very rare in the region.

\section{Taxonomic notes}

A. guttatus is strongly isolated from other members of the genus which constituted grounds for its segregation in the monotypic section of Aulacolobus Bunge. It is an annual plant, furnished with basifixed hairs. Racemes have a short peduncle, remotely 1-4 flowers. Calyx campanulate, with very unequal teeth, the lower three (abaxial) subulate, longer than tube, the upper (adaxial) distinctly shorter. Wings distinctly shorter than keel. Legumes stipitate, nodding, curved, incompletely bilocular, glabrous. The shape of fruits and bare stem branching from the distinguishes $A$. guttatus from other annual small species of the genus.

\section{Examined specimens (new records)}

RUSSIA: Stavropol Territory, Ipatovo District, near the village of Bolshaja Jalga, 19.05.1989, coll. V.N. Belous (SPI): 12; Krasnodar Territory, Taman peninsula, to the South from the Taman city, the mountain Zelenskaya, $45^{\circ} 14^{\prime} 47^{\prime \prime} \mathrm{N}$ 3669'06"E, $132 \mathrm{~m}$ a.s.l., steppe, clay, 29.04.2007, coll. V.N. Belous (SPI): 13; Stavropol Territory, Arzgyr District, northeast spurs of the Stavropol height, the right indigenous bank of the Chogray river, $45^{\circ} 22^{\prime} 41^{\prime \prime} \mathrm{N} 44^{\circ} 14^{\prime} 33^{\prime \prime} \mathrm{E}, 100 \mathrm{~m}$ a.s.l., hilly-beam relief elements, semidesert-steppe slope with ephemeretum, alluvial clay and loamy soils, 2.05.2015, coll. V.N. Belous (SPI): 14.

\section{Astragalus pallescens M. Bieb. (Fabaceae)}

\section{Contributor: Victor N. Belous}

\section{Distribution and habitat}

The distribution is Nomadic, the geoelement is Pontic. Black Sea endemic.

For the floras of adjacent areas, there are indications about the location of $A$. pallescens in the territory of the Lower Volga (Laktionov 2009) and the right bank of the Lower Don (Zozulin 1984). The species was discovered by us in the territory of the Kumo-Manych depression (valleylake landscapes of Western and Eastern Manych) (Belous 2011). Our latest finding in the North Caucasus mark the southern boundary of its range in Russia. This significantly expands the understanding of the chorological features of the $A$. pallescens.

\section{Taxonomic notes}

A. pallescens (section Dissitiflori DC., subgenus Cercidothrix Bunge) belongs to the group of perennial herbs with lignified stems and loose tassels. From close related $A$. macropus Bunge, the species differs by a set of the following characteristics: thin, densely and white-fluffy perennial stems and yellowish-white corolla.

\section{Examined specimens (new record)}

RUSSIA: Rostov Province, Orlovsky District, near the Manych village, the right bank of the West Manych river, elevated parts of the lower floodplain terrace of Manych-

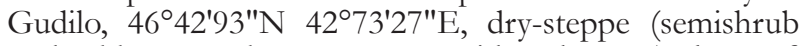
- shrubby - Herbae stepposae with ephemers) slope of Gruzskoe Lake, clay, 11.06.2008, coll. V.N. Belous (SPI): 15; Stavropol Territory, Arzgyr District, northeast spurs of the Stavropol height, $45^{\circ} 38^{\prime} 35^{\prime \prime} \mathrm{N} 44^{\circ} 24^{\prime} 12^{\prime \prime} \mathrm{E}$, hilly plain, the right indigenous bank of the Chogray river, carbonate dry-steppe slope, steppe (Festuca valesiaca + Stipa ucrainica - Herbae stepposae with ephemers), clay, rock debris of limestone, 2.05.2015, coll. V.N. Belous (SPI): 16.

\section{Astragalus physodes L. (Fabaceae)}

\section{Contributor: Victor N. Belous}

\section{Distribution and habitat}

A. physodes - Turanian species of the desert-steppe complex, Caspian-East Black Sea's endemic. It is characterized by a fragmented range in Eastern Black Sea-Volga's landscapes. Occurs on the Ergeni hill, the Lower Don and the Lower Volga (Goncharov et al. 1946, Zozulin 1984, Yakovlev et al. 1996, Baktasheva 2000, Laktionov 2009). Two close locations were cites for the North Caucasus. They are localized on the territory of the Terek-Sulak lowland in the North-Western Pre-Caspian (Grossgeim 1952, Murtazaliyev 2009). However, herbarium specimens confirming these data were not found during taxonomical revision of the genus Astragalus (Podlech \& Zarre 2013) and our own searches at the local Caucasian herbaria (LENUD, DAG).

Thus, we present the first reliable findings of $A$. physodes for the territory of the North Caucasus. Our findings are located $270 \mathrm{~km}$ to north-west from previous location, which are disputable.

\section{Taxonomic notes}

A. physodes belongs to section Cystium Bunge, subgenus Cercidothrix Bunge. It differs from other species the section by bare leaves, ovaries and fruits. Spherical swollen fruits are collected in dense brushes. The species is characterized by real physocarp.

\section{Examined specimens (new record)}

RUSSIA: Stavropol Territory, Arzgyr District, South Pre-Manych, northeast spurs of the Stavropol height, the right indigenous bank of the Chogray river, $45^{\circ} 22^{\prime} 40^{\prime \prime} \mathrm{N}$

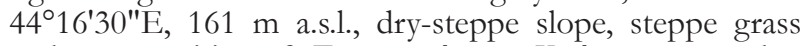
and communities of Festuca valesiaca, Koeleria cristata, clay, 2.05.2015, coll. V.N. Belous (SPI): 17.

\section{Astragalus somcheticus K. Koch (Fabaceae)}

\section{Contributor: Ramazan A. Murtazaliev}

\section{Distribution and habitat}

The species is spread in the Greater and Lesser Caucasus, as well as in northeastern Turkey (Podlech \& Zarre 2013). Within the Greater Caucasus, it is more often observed in Karachay-Cherkessia Republic and Kabardino-Balkaria Republic, as well as in the region of the Caucasian Mineral Waters. The main finds of the species in Armenia and Azerbaijan are confined to the southern borders (Grossheim 1952).

New locations were found for the first time in the Eastern Caucasus, namely in South Dagestan.

In the new location, the species is found on rocky and gravelly slopes of shale rocks in the middle and upper mountain belts.

\section{Taxonomic notes}

This species belongs to the section Incani DC., represented mainly by stemless perennials. In the Caucasus, this section includes about 30 species, most of which are endemic. This species combines two taxa that were previously taken as independent species: $A$. demetrii Charadze (Western and Central Greater Caucasus) and A. polygala Pall. (Central and Southern Transcaucasia, Turkey). 


\section{Examined specimens (new records)}

RUSSIA: Republic of Dagestan, Kurakhsky District, in

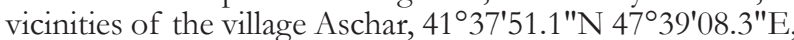
southeast slope, gravelly places, $1600 \mathrm{~m}$ a.s.l., 7.07.2010, coll. R.A. Murtazaliev s. n. (DAG): 18; Republic of Dagestan, Akhtynsky District, in vicinities of the village Lutkun, $41^{\circ} 29^{\prime} 06.4^{\prime \prime N} 47^{\circ} 42^{\prime} 47.7^{\prime \prime E}$, south-western slope, 1200 $1500 \mathrm{~m}$ a.s.l., 5.06.2012, coll. R.A. Murtazaliev s. n. (DAG, LE): 19; Republic of Dagestan, Dokuzparinsky District, the northeast slope of the mount Nesindag, $41^{\circ} 15^{\prime} 10.9^{\prime \prime} \mathrm{N}$ 47 48'10.9"E, 2700 m a.s.l., 5.08.2017, coll. R.A. Murtazaliev s. n. (LE): 20.

\section{Chloris virgata Sw. (Poaceae)}

\section{Contributors: Alexander L. Ebel \& Alla V. Verkhozina}

\section{Distribution and habitat}

C. virgata is widespread predominantly in warm temperate to tropical areas, but extending well into temperate regions with hot summer (Anderson 1974, Sun \& Phillips 2006). It is distributed in Asia (Afghanistan, Azerbaijan, Bhutan, China, India, Korea, Kyrgyzstan, Myanmar, Mongolia, Nepal, Pakistan, Russia (Far East), Saudi Arabia, Tajikistan), North, South and Central America, Africa, Australia, Pacific Islands (Rozhevitz 1934, Anderson 1974, Probatova 1985, Sun \& Phillips 2006). The species is included in the "Handbook of Alien Species in Europe" (Hulme 2009), and also was recorded in the Caucasus (Rozhevitz 1934, Tzvelev 2006).

In the Asian part of Russia, C. virgata was recorded as alien species in the Primorsky Territory, Khabarovsk Territory and the Amur Province (Probatova 1985, Antonova 2009, 2018, Starchenko \& Darman 2011). However, there is an assumption that the basin of the Razdolnaya River in Primorsky Territory is a part of its natural range (Probatova 2007).

C. virgata grows in many types of habitats, including cultivated farmland and such disturbed areas as roadsides and railroad tracks and (for example, in China) it is common on stony slopes, steppe, sandy riversides, roadsides, fields, plantations, frequent on walls and roofs; up to $3700 \mathrm{~m}$ a.s.l. (Sun \& Phillips 2006).

\section{Taxonomical notes}

The genus Chloris Sw. is represented by 63 species in tropical and warm-temperate regions throughout the world (The Plant List 2013).

C. virgata is the only species of the genus that grows in Russia in the wild. Other species of the genus $-C$. gayana Kunth (Rhodes Grass) is cultivated in Russia (Medvedev \& Smetannikova 1981).

C. virgata is considered the most variable of the all annual species in the genus. It varies in height, leaf size, tomentum and spikelet character. Only two attributes are given as constantly correlated and the species can be recognized by them: the conspicuous tufts of spreading, silky hairs on the upper lemma margins together with a digitate inflorescence of erect racemes (Anderson 1974). C. virgata closely resembles Ch. gayana in spikelet characters, but can be easily separated from it being an annual, having longer awns and lowest lemma with spreading longer hairs on upper margins (Anderson 1974, Sun \& Phillips 2006).

C. virgata is a new alien species to Siberia. A large number of specimens of Ch. virgata were found in Baikal Siberia during a field trip in 2017.

\section{Examined specimens (new records)}

RUSSIA: Zabaykalsky Territory, Zabaykalsk, 49³9'29.71"N $117^{\circ} 19^{\prime} 14.04^{\prime \prime E}$, railway deadlock, wasteland, 15.08.2017, coll. A.L. Ebel, A.A. Verkhozina, et al. 49796, 49480, 49481, 49483 (IRK, TK): 21; 49³8'27.21"N 117'19'57.69"E, roadside near the railway station, 15.08.2017, A.L. Ebel, A.A. Verkhozina, et al.. 49482, 49484, 49485 (IRK, TK): 22. $\times$ Elybordeum arcuatum W.W. Mitch. \& H.J. Hodgs. Elymus sibiricus L. $\times$ Hordeum jubatum L. (Poaceae)

Contributors: Alla V. Verkhozina, Alexander L. Ebel. \& Vladislav V. Murashko

\section{Distribution and habitat}

$\times$ E. arcuatum was described from disturbed sites around Palmer, Alaska, USA, from which it has been eliminated since it was sterile (Mitchell \& Hodgson 1968, Barkworth 2006).

This hybrid is relatively common in the Russian Far East (in Vladivostok and Khabarovsk), where it can be partially fertile (Probatova 1985).

$\times$ E. arcuatum grows on disturbed areas.

\section{Taxonomical notes}

$\times$ Elyhordeum Mansf. ex Tsitsin \& K.A. Petrova is the name given to hybrids between Elymus L. and Hordeum L., which are fairly common. All appears to be sterile, i.e. they do not produce viable pollen or set seed (Barkworth 2006) $\times$ Elybordeum represented by about 19 species in the world (The Plant List 2013). Most of them has Hordeum jubatum L. as one of their parent species. H. jubatum hybridizes in its native and non-native areas with a number of species of the genus Elymus.

Besides Elyhordeum $\times$ arcuatum, 2 other hybrids of Hordeum jubatum with species of the genus Elymus are known in the Asian part of Russia (mostly in the Far East): $\times$ Elyhordeum chatangense (Roshev.) Tzvel. (Hordeum jubatum $\times$ Elymus macrourus (Turcz.) Tzvel.), $\times$ Elyhordeum kolymense Prob. (Hordeum jubatum $\times$ Elymus pubiflorus (Roshev.) Peschkova (Probatova 1985, Peschkova 1990). Additionally, four new hybrids were revealed by D. Lysenko (2010) and named by him as $\times$ Elyhordeum detrinense Lysenko (Elymus jacutensis (Drob.) Tzvel. $\times$ Hordeum jubatum), $\times$ Elyhordeum khokhrjakovii Lysenko (Elymus kronokensis (Kom.) Tzvel. $\times$ Hordeum jubatum) $\times$ Elyhordeum olaense Lysenko (Elymus boreoochotensis Khokhr. $\times$ Hordeum jubatum) $\times$ Elyhordeum sinegoricum Lysenko (Elymus subfibrosus (Tzvel.) Tzvel. $\times$ Hordeum jubatum). Unfortunately, none of binomials supposed by Lysenko were accompanied by a Latin diagnosis, so they cannot be used in taxonomical practice.

Previously only one species of the nothogenus was known in Siberia, namely $\times$ Elyhordeum chatangense. It was described from Taymyr and is also found in Yakutia (Peschkova 1990).

$\times$ E. arcuatum was found in Irkutsk in 2015 and it is a new species to Siberia. It is distinguished from Hordeum jubatum by barely deflecting thin spines of lemmas, 2-3 times shorter than that of $H$. jubatum. The hybrid differs from Elymus sibiricus by slightly arcuate and very brittle thick spikes (Probatova 1985).

\section{Examined specimens (new record)}

RUSSIA: Irkutsk Province, Irkutsk city, University microdistrict, near the building $109,52^{\circ} 15^{\prime} 09.42^{\prime \prime N} 104^{\circ} 14^{\prime} 36.23^{\prime \prime} \mathrm{E}$, meadow between houses, 05.09.2015, A.A. Verkhozina. 44251-44257 (IRK): 23.

\section{Eritrichium pseudolatifolium Popov (Boraginaceae)}

Contributor: Svetlana V. Ovchinnikova

\section{Distribution and habitat}

E. pseudolatifolium was described from Kashgaria (China) and later was found in Eastern Pamir and Central and Eastern Tien Shan from the territory of Tadjikistan and Sinkiang in China (Popov 1953, Chukavina 1984, Ovchinnikova 2011), and was not found from the territory of Kyrgyzstan. E. pseudolatifolium grows in shaded crevices and foothill rocks in zone of high-mountain deserts and cryophil steppes at the altitudes $3700-4000 \mathrm{~m}$ a.s.l.

\section{Taxonomic notes}

The genus Eritrichium Schrad. ex Gaudin comprises 75 species of pubescent, sericeous or villous perennial cushion- 
forming herbs with distribution in the mountains of the Asia and Northern America, with 1-2 species in Europe (Ovchinnikova 2003). The 35 species of the subgenus Pseudobackelia (Popov) Ovczinnikova come across in the alpine zone of Southern and Central Asia (Ovchinnikova 2011). Three Eritrichium species were reported for Kyrgyzstan (Filatova \& Aidarova 1962, Ovchinnikova 2011).

E. psendolatifolium belongs to series Albiflora Popov of section Pseudohackelia Popov with drooping pedicels, white corolla, dorsiventrally compressed, short pubescent nutlets with triangular to lanceolate horizontally deflecting marginal glochids. From the related species of series Albiflora it is distinguished by an ovate to elliptic form of leaf blade and pressed pubescent pedicels (Ovchinnikova 2003, 2011).

E. psendolatifolium is a new species from the territory of Kyrgyzstan.

Examined specimens (new records)

KYRGYZSTAN: Eastern Tien Shan, basin of the Sarydzhaz River, Uchat Stream to the south from Taschkoroo village, on rocks, 14.08.1988, coll. M.G Pimenov, E.V. Kljuikov (MW0876566): 24.

\section{Eritrichium pseudostrictum Popov (Boraginaceae)}

Contributor: Svetlana V. Ovchinnikova

\section{Distribution and habitat}

E.psendostrictum was described from Pamir (Tadzhikistan) and later was found in Kashgaria (China) (Popov 1953, Chukavina 1984, Ovchinnikova 2011), and was not found from the territory of Kyrgyzstan.

E. pseudostrictum grows on rocks and scree of highmountains at the altitudes $3500-4200 \mathrm{~m}$ a.s.l.

\section{Taxonomic notes}

The 11 species of the section Himalaica (Popov) Ovczinnikova subgenus Pseudobackelia (Popov) Ovczinnikova come across in alpine zone (2700-5600 $\mathrm{m}$ a.s.l.l) of Himalaya, Tibet, Pamir-Alay in Tadzhikistan, Afganistan, Pakistan, India, Nepal (Ovchinnikova 2003, 2011). Three Eritrichium species were reported for Kyrgyzstan: E. tianschanicum Iljin ex Ovczinnikova (sect. Eritrichium), E. turkestanicum Franch. (sect. Himalaica), E. fetissovii Regel (sect. Psendohackelia) (Filatova \& Aidarova 1962, Ovchinnikova 2003, 2011).

E. pseudostrictum belongs to series Pamiralaica Ovczinnikova of section Himalaica (Popov) Ovczinnikova with upward protruding pedicels, blue corolla, turbinate, short pubescent nutlets with short upward protruding marginal glochids or almost fusing at base. From the related species E. canum (Benth.) Kitamura and E. dubium O. Fedtsch. it is distinguished by soddy growth and filiform leaves and original stellate prickly pericarpia of erems (Popov 1953, Ovchinnikova 2007, 2011).

E. pseudostrictum is a new species from the territory of Kyrgyzstan.

\section{Examined specimens (new records)}

KYRGYZSTAN: Alaiskii mountain range, basin of the Shakhimardan River, in headwater of Dugova River, alt. $3000 \mathrm{~m}$ a.s.l., on rocks, 4.08.1977, coll. O. Politova, S. Alekseev (MW0876106): 25.

\section{Lappula tuvinica Ovczinnikova (Boraginaceae)}

Contributors: Svetlana V. Ovchinnikova \&

Olga A. Chernysheva

\section{Distribution and habitat}

L. tuvinica was described from Siberia (Tyva Republic) and was found from the territory of $\mathrm{W}$ and C Siberia, E Kazakhstan, W Mongolia (Ovchinnikova 1997, 2009). Recently, it was reported from Eastern Siberia: Republic of Buryatia and Zabaykalsky Territory (Ovchinnikova \& Nikiforova 2016). L. tuvinica grows in desertified steppes and steppified meadows on rubbly and rocky slopes of mounds and foothills.

\section{Taxonomic notes}

The genus Lappula Moench comprises over 70 species of hispid small to medium-sized annual or perennial herbs with distribution in the northern Hemisphere and has several representatives in Africa and Australia (Ovchinnikova 2005). It belongs to series Lappula of section Lappula with subulate gynobase, ovate glochidiate nutlets with 1-3 rows of spinules. From the related species L. consanguinea (Fisch. et C.A. Mey.) Guerke it is distinguished by very small nutlets with minute spinules and tubercules along disc and all flanks (Ovchinnikova 2005, 2009).

\section{Examined specimens (new records)}

RUSSIA: Irkutsk Province, Ust-Orda Buryat Okrug, Ekhirit-Bulagatsky District, vicinity of Gushit village, Ordynskoe lake, $51^{\circ} 52^{\prime} 50^{\prime \prime} \mathrm{N}, 104^{\circ} 58^{\prime} 11^{\prime \prime E}, 548 \mathrm{~m}$ a.s.l., bank of the lake, 24.06.2010, coll. O.A. Chernysheva 52365 (IRK): 26.

\section{Lotus frondosus Freyn (Fabaceae)}

\section{Contributor: Ramazan A. Murtazaliev}

\section{Distribution and habitat}

Most often, the species is noted in Central Asia, but is found both to the west and east of the main part of the range, sometimes quite far, forming isolated locations (Yakovlev et al. 1996). In the Caucasus, the species was previously cited for Azerbaijan (Grossheim 1952). New locations are given for Dagestan on the old herbarium collections found in the Herbarium of the Komarov Botanical Institute RAS (LE). According to these collections, 4 localities of the species were identified, of which 3 are found in the coastal part of Dagestan, and one in the middle mountain zone, in the Sulak river basin. In these locations, the species is noted along the outskirts of rivers and lakes, in shrubs, and in the middle mountain zone, on gravelly slopes along the road.

\section{Taxonomic notes}

The species belongs to the section Eulotus Ser., to which most Caucasian species of this genus belong. L. frondosus differs from other species of section with a reddening corolla during flowering and drying.

\section{Examined specimens (new records)}

RUSSIA: North Caucasus, a salt lake near Petrovsk, 19.06.1894, coll. O.A. \& B.A. Fedtschenko s. n. (LE): 27; Dagestan, Distr. Kajtag.-Tabass., prope st. Kajakent. In pratis et inter frutices, 19.06.1899, coll. [F.N.] Alexeenko s. n. (LE): 28; Dagestan, Distr. Kurinsky. In ripa glareosa fl. Samur, pr. st. Jalominskaja, 400 m, 20.06.1899, coll. [F.N.] Alexeenko s. n. (LE): 29; Prov. Dagestan, Distr. Kajtag.-Tabass., pr. st. Kajakent. In fruticetis, 17.07.1900, coll. [F.N.] Alexeenko s. n. (LE): 30; Dagestan, Avar District, valley of Avar Koisu, below the village Gergebil, gravelly slope near the road, 28.08.1927, coll. A. Poretsky, G. Schulz s. n. (LE): 31.

\section{Medicago $\times$ varia Martyn (Fabaceae)}

(三M. sativa subsp. varia (Martyn) Arcang., M. sativa subsp. varia (Martyn) O. Bolos \& Vigo [isonim], M. sativa var. varia (Martyn) Urb.; = M. hemicycla Grossh., M. lavrenkoi Vassilcz., M. media Pers., M. ochroleuca Kult., M. rivularis Vassilcz., M. sylvestris Fr., M. tianschanica Vassilcz.)

Contributors: Denis A. Krivenko, Olga A. Chernysheva \& Olga Yu. Zavgorodnyaya

\section{Distribution and habitat}

The world's most important forage crop, alfalfa, belongs to the genus Medicago L. The species cultivated in the North Temperate Zone is usually $M . \times$ varia (Lesins \& Lesins 1979). It was found feral in Eastern Europe: Belarus, Estonia, Russia (European part), Ukraine, Caucasus: Armenia, 
Azerbaijan, Georgia, Russia (Caucasian part) and Asia: China, Kazakhstan, Kyrgyzstan, Tajikistan, Uzbekistan (Yakovlev et al. 1996, Shu 2010).

In Siberia, M. × varia was found feral in 2001 in the Altai Territory (Silantieva et al. 2003).

Recently, this species has widely spread eastward in the territory of the southern regions of Siberia to the Republic of Buryatia (Abramova et al. 2014, Ebel et al. 2017, Gamova 2018). In 2015, M. × varia was also found in the Russian Far East in the Khabarovsk Territory (Probatova et al. 2017). It was also indicated for the Irkutsk Province (Abramova et al. 2014), however, without a specific location and reference to the herbarium specimen. Thus, the locations in this article for the species are the only reliable in the Irkutsk Province at the present moment. This species is probably actively spreading on the disturbed habitats at the along of roadsides and in the vicinities of settlements and in the very near future we can expect new finds of it in Asian Russia.

\section{Taxonomic notes}

M. $\times$ varia is an amphiploid hybrid with $2 \mathrm{n}=32$ (tetraploid $(4 \mathrm{x})$, with $\mathrm{x}=8)$. Its progenitors are diploid $(2 \mathrm{x})$ with $2 \mathrm{n}=16$ species $M$. falcata L. and $M$. sativa $\mathrm{L}$. Both of them belong to the section Falcago Rchb. (Lesins \& Lesins 1964 1979). Different plants and a population of $M$. $\times$ varia show flowers color ranging from violet to yellowish with all variations between these, and have legumes with less than one to two circles. These characters are possessed by $M$. falcata with yellow flowers and legumes straight or sickle-shaped at one extreme and by $M$. sativa with violet flowers and legumes coiled from one and a half circle to three circles at the other. The variegated color of the flowers of $M . \times$ varia in the herbarium are not always preserved, however, we noted that they often turn brown when desiccated. Below is the key that will permit one to more or less reliably identify $M . \times$ varia and related species from the section Falcago inha biting Asian Russia.

Key to the Medicago L. of section Falcago Rchb. species confirmed for Asian Russia

1. Stems strong, flowers yellow or yellow and blue variegated, legumes from sickle-shaped to two circles .............................. 2 + Stem procumbent, flowers bluish-purple or bluish-violet, legumes coiled from one and a half circle to three circles ....

M. sativa L.

2. Flowers in varying degrees of intensity yellow and blue variegated, often when desiccated turn brown

M. × varia Martyn

+ Flowers yellow, legumes straight or sickle-shaped, coiled in not more than one half-circle, leaflets of lower leaves reverse ovoid-lanceolate, and of upper reverse lanceolate

M. falcata L. var. falcata

++ Leaflets of lower leaves reverse lanceolate, and of upper reverse linearly-lanceolate

M. falcata var. romanica (Prodan) Hayek

\section{Examined specimens (new records)}

RUSSIA: Irkutsk Province, Zalarinsky District, before of Tyret Pervaya urban-type settlement, bridge over Unga river, $53^{\circ} 39^{\prime} 43.69^{\prime \prime} \mathrm{N}, 102^{\circ} 21^{\prime} 09.60^{\prime \prime} \mathrm{E}$, red carbonate slope, 17.08.2009, coll. O.A. Chernysheva 52903, 52905 (IRK): 32; Irkutsk Province, Ust-Kut town, right bank of Kuta River, Ust-Kut sanatorium $56^{\circ} 47^{\prime} 22.47^{\prime \prime} \mathrm{N}, 105^{\circ} 36^{\prime} 59.04^{\prime \prime} \mathrm{E}$, on a meadow by the salt lake, 20.07.2010, coll. O.A. Chernysheva 46055, 46056 (IRK): 33; Irkutsk Province, Irkutsk city, Akademgorodok, $461 \mathrm{~m}$ a.s.l., 52 $14^{\prime} 25^{\prime \prime} \mathrm{N} 104^{\circ} 16^{\prime} 22^{\prime \prime} \mathrm{E}$, weedruderal communities, 22.06.2017, coll. D.A. Krivenko 52981 , 52982 (IRK), 52983 (MW): 34; Irkutsk Province, Irkutsk city, Akademgorodok, 52 $14^{\prime} 14.09^{\prime \prime} \mathrm{N}, 104^{\circ} 16^{\prime} 17.01^{\prime \prime} \mathrm{E}$, on edge of the pedestrian path, 23.06.2017, D.A. Krivenko 49970, 49971 (IRK), 49972 (MW): 35; Irkutsk Province, Irkutsky District, Listvyanka urban-type settlement, SW shore of
Baikal Lake, $466 \mathrm{~m}$ a.s.l., $52^{\circ} 22^{\prime} 02^{\prime \prime} \mathrm{N}, 104^{\circ} 49^{\prime} 57^{\prime \prime} \mathrm{E}$, roadside, 3.07.2017, coll. D.A. Krivenko 52916, 52917 (IRK), 52918 (MW), 52919 (LE): 36; Irkutsk Province, Irkutsk city, right bank of Angara river, Solnechnyi microdistrict, $473 \mathrm{~m}$ a.s.l., $52^{\circ} 15^{\prime} 30.2^{\prime \prime N} 104^{\circ} 20^{\prime} 51.0^{\prime \prime} \mathrm{E}$, roadside, 22.08.2018, coll. D.A. Krivenko 51114 (IRK): 37; Irkutsk Province, Irkutsky District, SW shore of Baikal Lake, estuary of Pylovka, 94th $\mathrm{km}$ of Circum-Baikal Railway, $456 \mathrm{~m}$ a.s.l., $51^{\circ} 48^{\prime} 01^{\prime \prime} \mathrm{N}$, $104^{\circ} 34^{\prime} 11^{\prime \prime E}$, lake shore, 15.09.2018, coll. O.Yu. Zavgorodnyaya 52984 (IRK): 38

\section{Persicaria orientalis (L.) Spach (Polygonaceae)}

Contributor: V.V. Murashko

\section{Distribution and habitat}

P. orientalis was described from SE Asia (Tzvelev 1989). It is native to SE Asia and mostly northern Australia (Grossheim 1945, Walsh \& Entwisle 1994). The secondary areal is wide enough, and covers rest of Asia, Europe, North and South America, Australia and Oceania (Komarov 1936, Walsh \& Entwisle 1994, Li et al. 2003, Hinds \& Freeman 2005, Kantachot et al. 2010). P. orientalis is often cultivated and occasionally persisting in abandoned gardens. In most cases it is adventive, due to the rather frequent use as introduced plant. So, for example, there is an assumption that collection made in 1853 by F.V. Hayden at Fort Pierre, South Dakota (MO) to have come from a cultivated plant (Hinds \& Freeman 2005).

$P$. orientalis is an adventive species for Russia distributed there in the European part and the Far East (Komarov 1936, Majorov et al. 2012, Golovanov \& Muldashev 2017). It is growing mainly along roadsides, near houses, on wastelands (Komarov 1936). The species previously was not cited for Siberia.

\section{Taxonomical notes}

P. orientalis belongs to the section Amblygonon (Meisn.) Tzvelev (Tzvelev 1988, 1989), which contain 2 species (P. orientalis and P. pilosa (Roxb.) Kitag.). The main feature of the section is a greenish and bent out tips of ocreas. Species belonging to this section have larger flowers than those of sect. Persicaria (Tzvelev 1988).

$P$. orientalis have less abundant downiness of stem and leaf (with more pressed trichomes) than P. pilosa. The inflorescence length of $P$. orientalis is $5-10 \mathrm{~cm}$, while $P$. pillosa has $2.5-6 \mathrm{~cm}$. The perianth $P$. orientalis has a brighter color (hot pink or almost red) and some larger. Both species have two stigmas, but the stylodium of $P$. orientalis is much shorter, only $0.2-0.6 \mathrm{~mm}$ (P. pilosa has $0.8-1.5 \mathrm{~mm}$ ) (Tzvelev 1989).

\section{Examined specimens (new record)}

RUSSIA: Irkutsk Province, Irkutsk City, Novo-Lenino microdistrict, crossing of 6th Soviet Lane and Telman street, $52^{\circ} 20^{\prime} 18.70^{\prime \prime} \mathrm{N} 104^{\circ} 11^{\prime} 44.68^{\prime \prime} \mathrm{E}$, an abandoned wasteland, two meters from the road, 08.25.2018, coll. V.V. Murashko. 52910-52913 (IRK): 39.

\section{Thalictrum amurense Maxim. (Ranunculaceae)}

Contributors: Alexander N. Luferov \& Nikolai V. Friesen Distribution and habitat

Thalictrum amurense Maxim. is not listed in the reports on the flora of Japan (Ohwi 1965, Emura 1972, Tamura 1972, Kadota 2006). This species was considered to grow only on the mainland: in the Russian Far East - Primorsky Territory and Khabarovsk Territory, Amur Province, Jewish Autonomous Province, and in Northeast China and the Korean Peninsula (Luferov 1992, 2004, 2015, 2016). It grows in upland and floodplain meadows, forest edges and along roadsides (Luferov 1995)

\section{Taxonomic notes}

The species independence of T. amurense was not previously recognized by some botanists: this species was considered as a synonym for T. simplex L. (Komarov 1903), 
T. simplex var. affine (Ledeb.) Regel (Regel 1861, Kitagawa 1979) or T. flavum L. (Nevski 1937, Emura 1972). At present, taxonomic isolation of $T$. amurense is confirmed by morphological, anatomical, ecological-geographical, phenological and biochemical features (Woroshilov 1961, 1982, Ponomarchuk \& Ulanova 1977; Luferov 1992, 1995). Views towards relationships of the T. amurense family are different: V.N. Woroshilov (1961) noted that this species is close to T. simplex, T. flavum and T. angustifolium Jacq. (primarily called T. lucidum L.). According to Ponomarchuk \& Ulanova (1977), only T. simplex is the closest species to T. amurense.

T. amurense is a plant up to $220 \mathrm{~cm}$ tall, with short underground rhizomes and bunches of numerous lemon-yellow adventitious roots; sometimes with thin stoloniferous rhizomes up to $30 \mathrm{~cm}$ long. Stems straight, ribbed, branched at the top and slightly wavy. Leaves $5-20 \mathrm{~cm}$ long, 3-12 cm wide, oblong-triangular, bipinnate or tripinnate, biternate or triternate, appressed to the stem; 1-4 basal leaves, widetriangular, reclinated from the stem. Leaflets $2-7 \mathrm{~cm}$ long, 0.5-1.5 cm wide, oblong-obovate, lanceolate, oblongrhombic, 3-5-dentate, base cuneate; blades dark green and shiny on the upper surface, light green and dull beneath, with sharply protruding veins. Inflorescence a narrow pyramidal panicle. Pedicels $2-4(6)$ together, straight or slightly curved, $0.4-1.2 \mathrm{~cm}$ long. Tepals and anther filaments light yellow. Stamens 3-5 mm long. Anthers linear, 1-2 mm long. Pistils 5-12 in number, style oblong-triangular. Achenes 3-3.5 mm long, 1-1.5 mm wide, ovoid or elliptical.

\section{Examined specimens (new records)}

The study of herbarium collections stored at the V.L. Komarov Botanical Institute (St. Petersburg) allowed identification of samples of $T$. amurense for the first time for Japan. Their labels are listed below: "Japonia, Nagasaki, inter Idzinohari et Kundsho-san, 23 Septem. / 5 Okt. 1863, coll. Maximowicz" (LE): 40; "Hondo, Koshigaya in Kotsuke, 28 Jul. 1951, №. 321, coll. J. Ohwi” (LE): 41.

\section{Vicia bithynica (L.) L. (Fabaceae)}

Contributor: Ramazan A. Murtazaliev

\section{Distribution and habitat}

The common range of the species covers the Mediterranean countries, in many of which it is invasive. In the Caucasus, the species is distributed in Azerbaijan and Georgia (Grossheim 1952). Within the Russian Federation, it is known in the Krasnodar Territory (along the Black Sea coast), and the species is also found in the Crimea (Yena 2012). Previously, the species was not presented for the flora of Dagestan (Murtazaliev 2009). New locations identified for the territory of Dagestan on charges stored in the Herbarium of the Komarov Botanical Institute of RAS (LE). Three localities were identified in South Dagestan: two points in the vicinity of Derbent and one in the valley of the Samur River.

\section{Taxonomic notes}

Annual plant with few-flowered brush, which is longer than leaves. It differs from other species by large up to $10 \mathrm{~mm}$ or more, sharply toothed-notched stipules.

\section{Examined specimens (new record)}

RUSSIA: [Republic of Dagestan, Akhtynsky District] in rivulorum littore pr. pagum Zrych, 16.06.1830, coll. C.A. Meyer s. n. (LE): 42; Prov. Dagestan, Derbent, in herbosis angustiarum Sary-Kaja, 22.04.1902, coll. [F.N.] Alexeenko s.n. (LE): 43; Prov. Dagestan, Derbent, ad viam versus p. Sabnova, 30.04.1902, [F.N.] Alexeenko s. n. (LE): 44.

Viola hirta L. (Violaceae)

Contributors: Denis A. Krivenko \& Alla V. Verkhozina

\section{Distribution and habitat}

$V$. hirta is found in Caucasus, irregularly throughout Europe (mainly in the southern part), including European
Russia, in southern Siberia (Valentine et al. 1968, Nikitin 1996, Nikitin \& Silantieva 2006) and is also known isolated from a location in the Chinese province of Xinjiang (Shu 2007). The eastern boundary of the species range is in Republic of Khakassia and Krasnoyarsk Territory (Vyltsan 1977). Earlier, the species was also indicated for the territory of the Irkutsk Province by M.G. Popov (1957), however, it was not cited in later floristic works on the flora of Siberia (Ivanova 1979, Zuev 1996, 2012).

The first reliable finding of $V$. birta in the Irkutsk Province was made by us in 2009 on the border of the Irkutsk Province and the Krasnoyarsk Territory, in the vicinity of the village of Shelaevo on a railway embankment. In 2015, the species was collected at this location again, but in a birch forest. Probably in the west of the Irkutsk Province passes the eastern boundary of the range of this species.

$V$. hirta grows in sparse forests, in thicket of shrubs, on edge of forests and grass of slopes as well as like most species of violets in disturbed habitats.

\section{Taxonomic notes}

$V$. hirta is a close relative of $V$. collina Besser and $V$. thomasiana Songeon \& E.P. Perrier. All of them belong to the section Viola. These taxa differ mainly in the character of leaf blades: round heart-shaped, maximum width near the middle in $V$. collina vs. oblong-triangular heart-shaped, maximum width is in its lower third in $V$. birta and $V$. thomasiana, and in stipules: long fringed, ciliated $V$. collina vs. whole or short-fringed, not ciliated. In turn, $V$. thomasiana are more miniature plants than $V$. hirta (Nikitin \& Silantieva 2006).

\section{Examined specimens (new records)}

RUSSIA: Irkutsk Province, Tayshetsky District, NE vicinity of Shelaevo village, $56^{\circ} 55^{\prime} 53.6^{\prime \prime} \mathrm{N} 97^{\circ} 41^{\prime} 08.8^{\prime \prime} \mathrm{E}$, railway mound, 21.06.2009, coll. A.V. Verkhozina 47509, 52946 (IRK): 45; Irkutsk Province, Tayshetsky District, behind of Shelaevo village, Solonechnoye Lake, left bank of Biryusa River, $56^{\circ} 55^{\prime} 57.41^{\prime \prime} \mathrm{N} 97^{\circ} 40^{\prime} 52.79^{\prime \prime} \mathrm{E}$, tall grass of birch forest, 26.07.2015, coll. D.A. Krivenko 41871 (MW), 41872 (VLA), 41873 (IRK): 46.

\section{Viola suavis M. Bieb. (Violaceae)}

\section{Contributor: Denis A. Krivenko \\ Distribution and habitat}

$V$. suavis s. l. is a species native in forests, forest edges and other shady places in S Europe, Caucasus, Asia: N West and W Middle (Yuzepchuk 1949, Valentine et al. 1968). In Russia, the species is found in south of European and Caucasian parts. The eastern boundary of its range passes in Saratov Province (Nikitin 1996, 2014). Earlier this species for Asian Russia was not known, as well as other species of violets with stolons belonging to the section Viola (Zuev 2012). Only in 2015, an endemic species for Altai Territory $V$. taynensis T. Elisafenko \& Ovczinnikova from a typical section was described (Elisafenko 2015, Elisafenko \& Ovchinnikova 2015). The last taxon, however, is doubtful, and in need of further study.

$V$. suavis has the potential for secondary distribution, so it was discovered as adventive species in northern European countries of Norway (Marcussen \& Nordal 1998) and Poland (Nobis et al. 2015). The location of $V$. suavis we discovered in Siberia is clearly secondary, since it was herbarized in forest plantations of Pinus sylvestris L. The final conclusion about the origin of this species in Siberia can be made, probably, after a detailed examination the ribbon-like pine forest on Kasmala River adjacent to forest plantations of P. sylvestris.

\section{Taxonomic notes}

Viola suavis is most similar to $V$. taynensis and $V$. odorata $\mathrm{L}$. The three species can be easily confused. These taxa differ 
mainly in the character of stipules, in stolons and in color of flowers (Yuzepchuk 1949, Nikitin 2014, Elisafenko 2015). Stipules of long fringed-ciliated, flowers of half purple and white, stolons of short and stout in $V$. suavis vs. stipules short fringed or whole, flowers purple, stolons of long, procumbent and rooting in $V$. taynensis and $V$. odorata.

\section{Examined specimens (new records)}

RUSSIA: Altai Territory, Rebrikhinsky District, between Voronikha and Rozhnev Log villages, 52 $47^{\prime} 47^{\prime \prime} \mathrm{N}$ $82^{\circ} 20^{\prime} 33^{\prime \prime E}$, forest plantations of Pinus sylvestris, 27.09.2018, coll. D.A. Krivenko 52924, 52925 (IRK), 52926 (MW): 47.

\section{Thymus gobi-altaicus (N. Ulziykh.) Kamelin \\ \& A.L. Budantzev (Labiatae)}

(三Th. gobicus subsp. gobi-altaicus N. Ulziykh.)

Contributors: Andrey Yu. Korolyuk, Stepan A. Senator, Evgenii G. Zibzeev \& Vladimir M. Vasjukov

\section{Distribution and habitat}

Th. gobi-altaicus is a rare and endemic species of SouthWest Mongolia. Until recently it was known only by type specimen "P.R.M. Gobi-Altai, jugum Arcz-Bogdo, montana Bag-Bajan, montana-steppa, in schistosis unacum Juniperus psendosabina, 10 August 1967, coll. N. Ulzijchutag, P. Aygangonor" (UBA).

\section{Taxonomic notes}

The dwarf shrub with stems ending with a lying vegetative shoot. The stems are smoothly tetrahedral, evenly pubescent along the entire length with short hairs. Generative shoots are unbranched. Leaves are elliptical-lanceolate, up to $2 \mathrm{~mm}$ wide, with entire edges, petiolate, densely pubescent with long hairs above and below. Inflorescence is compact. The calyx reaches a length of $4.5-5 \mathrm{~mm}$ in flowering time.

Th. gobi-altaicus is mostly close to Th. gobicus Tscherneva s. str. (leaves are $2-3 \mathrm{~mm}$ wide, pubescent above and naked below). According to Kamelin \& Budantsev (1990), Th. gobi-altaicus belongs to the series Praeserpylla Klokov, which includes mostly Far Eastern species with pubescent leaves, and differs from other species of this series by sparser and shorter pubescence of stalks, narrower leaves coated only by long hairs vs. both long and short hairs in other species. Th. gobi-altaicus is possibly similar to the South Altai species Th. narymensis Serg., from which it differs by a larger calyx.

\section{Examined specimens (new records)}

MONGOLIA: Taishir, $1637 \mathrm{~m}$ a.s.l., 46 42'18.4"N 96 34'51.2"E, 21.07.2018, coll. A.Yu. Korolyuk, S.A. Senator, E.G. Zibzeev (MW, PVB): 48.

\section{ACKNOWLEDGEMENTS}

The reported study was funded by RFBR (grants 1744-388084, 18-04-00653, 18-34-20056, 19-04-00658) RSF (grant 16-16-00080, on Medicago species, Programme AAAA-A17-117012610055-3 of the Central Siberian Botanical Garden SB RAS, Tomsk State University competitiveness improvement programme, Government of Irkutsk Province grant and Supported by the Russian Academic Excellence Project 5-100 (Sechenov University). Special gratitude to Eric DeChaine (Western Washington University, Bellingham, USA), Matt Berger (California, USA) and Vanessa Robinson (Thompson Rivers University, Kamloops, British Columbia, Canada) for linguistic editing.

\section{LITERATURE CITED}

Abramova, L.A., P.A. Volkova, S.V. Dudov, A.A. Bobrov \& Yu.O. Kopylov-Guskov 2014. Findings of new, adventive and rare for Buryatia species of vascular plants on the territory of Altachejsky reserve (Mukhorshibirsky district). Turczaninowia 17(4):69-73 (in Russian). [Абрамова А.А., Волкова П.А., Аудов С.В., Бобров А.А., Копылов-Гуськов Ю.О. 2014. Находки новых, заносных и реАких Аля Бурятии видов сосудистых растений на территории А^тачейского заказника (Мухоршибирский район) // Turczaninowia. T 17, № 4. С. 69-73].

Anderson, D.E. 1974. Taxonomy of the genus Chloris (Gramineae). Brigham Young University Science Bulletin, Biological Series 19(2):1-131.

Antonova, L.A. 2009. Alien flora cadastre of Khabarousk region. DVO RAN, Vladivostok \& Khabarovsk, 93 pp. (in Russian). [Антонова А.А. 2009. Конспект аАвентивной флоры Хабаровского края. ВАадивосток; Хабаровск: $\triangle \mathrm{BO}$ PAH. 93 c.].

Antonova, L.A. 2018. New alien species and alien species of rare occurrence in the flora of Khabarovsky Territory. Turczaninowia 21(3):97-101 (in Russian). [Антонова А.A. 2018. Новые и редко встречающиеся аАвентивные вилы во флоре Хабаровского края // Turczaninowia. T. 21, № 1. С. 97-101].

Baktasheva, N.M. 2000. Flora of the Kalmykia and its analysis. Dzhangar, Elista, 136 pp. (in Russian). [Бакташева H.M. 2000. Фцора Каммыкии и ее анализ. Элиста: Ажангар. 136 c.].

Barkworth, M.E. 2006. ×Elyhordeum Mansf. ex Tsitsin et K.A. Petrova. In: Flora of North America North of Mexico: Magnoliophyta: Commelinidae (in part): Poaceae (part 1), vol. 24 (M.E. Barkworth, K.M. Capels, S. Long \& L.K. Anderton, eds), pp. 283-287, Oxford University Press, New York \& Oxford.

Belous, V.N. 2006. The Astragalus's abstract of the flora of Ciscaucasia. In: Rol' osobo okhranyayemykh prirodnykh territorii v sokhranenii bioraznoobraziya (A.V. Shmaraeva, ed.), pp. 110-113, Izdatel'stvo Rostovskogo universiteta, Rostov-na-Donu (in Russian). [Белоус B.H. 2006. Конспект астрагалов флоры Предкавказья // Роль особо охраняемых природных территорий в сохранении биоразнообразия / под реА. А.В. Шмараевой. Ростов-на-Аону: Иза-во Ростовского университета. C. 110-113].

Belous, V.N. 2011. To a question of flora and vegetation of steppe ecosystems of Primanychye (Kumo-Manych lowland). Florologiya $i$ Phytosozologiya 2:116-122 (in Russian). Белоус В.Н. К вопросу и растительности степных экосистем Приманычья (Кумо-Манычская низменность) // ФАорологія и фітосозоологія. Т. 2. С. 116-122].

Bulavkina, A.A. 1937. Aquilegia L. In: Flora of the USSR, vol. 7 (V.L. Komarov, ed.), pp. 69-79, Izdatel'stvo AN SSSR, Moscow \& Leningrad (in Russian). [Булавкина А.А. 1937. Aquilegia L. // ФАора CССР, т. 7 / поА реА В. А. Комарова. М.; А.: ИзА-во АН СССР. С. 69-79].

Chukavina, A.P. 1984. Eritrichium Schrad. ex Gaudin. In: Flora of Tajik SSR, vol. 7 (A.P. Chukavina, ed.), pp. 452460, Nauka, Leningrad (in Russian). [Чукавина А.П. Eritrichium Schrad. ex Gaudin // ФАора ТаАжикской ССР, т. 8 / под реА. А.П. Чукавиной. $\Lambda .:$ Наука. C. 452-460].

Ebel, A.L., S.I. Mikhailova, T.O. Strelnikova, S.A. Sheremetova, N.N. Lashchinskiy \& T.V. Ebel. 2017. New and rare alien species for the Republic of Khakassia. Turczaninowia 20(1):52-67 (in Russian). [Эбель А.А., Михайлова С.И., Стрельникова Т.О., Шереметова С.А., Аащинский Н.Н., Эбель Т.В. 2017. Новые и редкие Аля Хакасии чужеродные виды растений // Turczaninowia. T. 20, № 1. C. 52-67]. 
Elisafenko, T.V. \& S.V. Ovchinnikova 2015. Lectotypification of Viola taynensis (Violaceae). Rastitel'nyi Mir Asiatskoi Rossii 4:12-13 (in Russian). [ЕАисафенко T.B., Овчинникова С.В. 2015. Аектотипификация Viola taynensis (Violaceae) / / Растительный мир Азиатской России. № 4. C. 12-13].

Elisafenko, T.V. 2015. New species of the genus Viola (Violaceae) from Siberia. Rastitel'nyi Mir Asiatskoi Rossii 1:2025 (in Russian). [Елисафенко Т.В. 2015. Новый виА posa Viola (Violaceae) из Сибири // Раститемьный мир Азиатской России. № 4. С. 20-25].

Emura, K.M.H. 1972. Cytotaxonomical studies on the genus Thalictrum in Eurasia with special reference to Japanese species. Journal of the Faculty of Science: University of Tokyo, Section 3, Botany 11:93-135.

Erst, A.S. \& O.V. Vaulin 2014. Phylogenetic relationships among North Asian species of the genus Aquilegia based on molecular markers. Russian Journal of Genetics: Applied Research 4(1):35-42.

Erst, A.S., A.N. Luferov, K. Xiang \& W. Wang 2016. A review of the genus Aquilegia L. (Ranunculaceae) in Mongolia. Systematic notes on the materials of P.N. Krylov Herbarium of Tomsk State University 114:37-48 (in Russian). [Эрст A.C., Ауферов А.Н., Ксианг К., Ванг В. 2016. Конспект роAa Aquilegia L. (Ranunculaceae) фморы Монголии // Систематические заметки по материалам Гербария Томского государственного университета. №. 114. C. 37-48].

Erst, A.S., D.N. Shaulo \& A.A. Kuznetzov 2013. Aquilegia daingolica (Ranunculaceae), a new species from Mongolia. Systematic notes on the materials of P.N. Krylov Herbarium of Tomsk State University 108:14-22 (in Russian). [Эрст A.C., Шауло А.Н., Кузнецов А.А. 2013. Aquilegia daingolica (Ranunculaceae) - новый виА из Монголии // Систематические заметки по материалам Гербария Томского государственного университета, № 108. С. 14-22].

Filatova, N.S. \& R.A. Aidarova 1962. Eritrichium Schrad. In: Flora of KirghizSSR, vol. 10 (A.I. Vvedenskii, ed.), pp. 87-88, Izdatel'stvo AN Kirghizkoi SSR, Frunze (in Russian). [Фиматова Н.С., Айларова Р.А. 1962. Eritrichium Schrad. // ФАора Киргизской ССР, т. 10 / под реА. А.И. ВвеАенского. Фрунзе: Иза-во АН Киргизской ССР. С. 87-88].

Fischer, F.E.L. \& R. Avé-Lallemant 1840. Index Seminum, quae Hortus Botanicus Imperialis Petropolitanus pro Mutua Commutatione Offert. Accedunt Animadversiones Botanicae Nonnullae. St. Petersburg, 6(2):43.

Friesen, N.V. 1993. Aquilegia L. In: Flora of Siberia: Portulacaceae-Ranunculaceae, vol. 6 (L.I. Malyshev \& G.A. Peshkova, eds), pp. 112-116, Nauka, Novosibirsk (in Russian). [Фризен Н.B. Aquilegia L. // ФАора Сибири: Portulacaceae-Ranunculaceae, т. 6 / под реА. А.И. Малышева и Г.А. Пешкова. Новосибирск: Наука. С. 112-116].

Galushko, A.I. 1980. Flora of the North Caucasus, vol. 2. Izdatel'stvo Rostovskogo universiteta, Rostov-na-Donu, 352 pp. (in Russian). [Галушко А.И. ФАора Северного Кавказа. Ростов-на-Аону: ИзА-во Ростовского университета. Т. 2. 352 с.].

Gamova, N.S., S.V. Dudov, A.V. Sutkin \& A.S. Krasnopevtseva 2018. New and rarely found in Buryatia taxa of adventive plants from the buffer zone of the Baikal Nature Reserve. Turczaninowia 21(3):12-20 (in Russian). [Гамова Н.С., Аудов С.В., Суткин А.В., Краснопевцева А.С. 2018. Новые и реАко встречающиеся в Бурятии таксоны адвентивных растений из охранной зоны Байкальского заповедника // Turczaninowia. T. 21, № 3. C. 12-20].
Golovanov, Ya.M. \& A.A. Muldashev 2017. Findings of new and rare adventive plant species in the flora of the Republic of Bashkortostan. Phytodiversity of Eastern Europe 11(1):54-62 (in Russian). [Голованов Я.М., Мулаашев А.А. 2017. Находки новых и редких адвентивных видов растений во флоре Республики Башкортостан // Фиторазнообразие Восточной Европы. Т. 11, № 1. C. 46-47].

Goncharov, N.F., M.G. Popov, A.G. Borisova, A.A. Grossheim, S.G. Gorshkova \& I.T. Vasilchenko 1946. Astragalus L. In: Flora of the USSR, vol. 12 (B.K. Shishkin ed.), Izdatel'stvo AN SSSR, Moscow \& Leningrad, 918 pp. (in Russian). [Гончаров Н.Ф., Попов М.Г., Борисова А.Г., Гроссгейм А.А., Горшкова С.Г., Васильченко И.Т. 1946. Astragalus L. // ФАора СССР, т. 12 / пол реА. Б.К. Шишкина. М.; А.: ИзА-во АН СССР. 918 с.].

Grossheim, A.A. 1945. Flora of the Caucasus, vol. 3. Izdatel'stvo AN Azerbaydzhanskoi SSR, Baku, 509 pp. (in Russian). [Гроссгейм А.А. 1945. ФАора Кавказа. Баку: ИзАательство АН АзербайАжанской ССР. Т. 3. 509 с.].

Grossheim, A.A. 1952. Flora of the Caucasus, vol. 5. Izdatel'stvo AN SSSR, Moscow \& Leningrad, 740 pp. (in Russian). [Гроссгейм А.А. 1952. ФАора Кавказа. М.; $\Lambda$. : Иза-во АН СССР. Т. 5. 740 с.].

Hinds, H.R. \& C.C. Freeman 2005. Persicaria (L.) Mill. In: Flora of North America North of Mexico: Magnoliophyta: Caryophyllidae (part 2), vol. 5 (Flora of North America Editorial Committee, ed.), pp. 574-594, Oxford University Press, New York \& Oxford.

Hulme Ph.E. (ed.) 2009. Handbook of alien species in Europe. Springer, The Netherlands, 399 pp.

Ivanova, M.M. 1979. Viola L. In: Flora of Central Siberia, vol. 2 (L.I. Malyschev \& G.A. Peshkova, eds), pp. 657-663, Nauka, Novosibirsk (in Russian). [Иванова M.M. 1979. Viola L. // ФАора Центральной Сибири, т. 2 / поА ред. А.И. Малышева и Г.А. Пешковой. Новосибирск: Наука. С. 657-663].

Kadota, Y. 2006. Thalictrum L. In: Flora of Japan, vol. II a (K. Iwatsuki, D.E. Bouford \& H. Ohba, eds), pp. 333 341, Kodansha, Tokyo.

Kamelin, R.V. \& A.L. Budantsev 1990. The review of Thymus L. species from Mongolia. Byulleten' Moskovskogo Obshchestva Ispytatelei Prirody, Otdel Biologicheskii 95(3):91-98 (in Russian). [Камелин Р.В., Буданцев А.А. 1990. Обзор видов рода Thymus L. во фморе МHР // Бюлметень МОИП. ОтАел биологический. Т. 95, вып. 3. С. 91-98].

Kantachot, C., P. Chantaranothai \& D.A. Simpson 2010. A synopsis of the genus Persicaria (Polygonaceae) in Thailand. Thai Forestry Bulletin (Botany) 38:128-149.

Kitagawa, M. 1979. Neo-Lineamenta Florae Manshuricae. Flora et vegetatio mundi, vol. 4. Gantner, Vaduz, $717 \mathrm{pp}$.

Komarov, V.L. 1903. Flora of Manchuria. Trudy Imperatorskogo Sankt-Peterburgskogo botanicheskogo sada 22(1): 1-787 (in Russian). [Комаров В.А. ФАора Маньчжурии // Труды Императорского Санкт-Петербургского ботанического сала. Т. 22, вып. 1. С. 1-787].

Komarov, V.L. 1936. Polygonum L. In: Flora of the USSR, vol. 5 (V.L. Komarov ed.), Izdatel'stvo AN SSSR, Moscow \& Leningrad, pp. 594-702 (in Russian). [Комаров B.А.

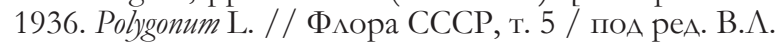
Комарова. М.; А.: ИзА-во АН СССР. С. 594-702].

Laktionov, A.P. 2009. Flora of the Astrakhan region. Izdatel'skii dom Astrakhanskii universitet, Astrakhan, 296 pp. (in 
Russian) [Аактионов А.П. 2009. ФАора Астраханской области. Астрахань: Издательский дом Астраханский университет. 296 с.]

Ledebour, C.F. 1843. Flora Rossicasive Enumeratio Plantarum in Totius Imperii Rossici Provinciis Europaeus, Asiaticis, et Americanus Hucusque Observatarum, vol. 1(3). Stuttgartiae, 736 pp.

Lesins, K. \& I. Lesins 1964. Diploid Medicago falcata L. Canadian Journal of Genetics and Cytology 6(2):152-163.

Lesins, K.A. \& I. Lesins 1979. Genus Medicago (Leguminosae): a taxogenetic study. Springer, Dordrecht, 228 pp.

Li, A., A.E. Grabovskaya-Borodina, S. Hong, J. McNeill, H. Ohba, Ch. Park 2003. Polygonum L. In: Flora of China: Ulmaceae through Basellaceae, vol. 5 (W. Zhengyi, P.H. Raven \& H. Deyuan, eds), pp. 278-315, Science Press \& MBG Press, Beijing \& St. Louis.

Luferov, A.N. 1992. Typification of some Far-Eastern species of family Ranunculaceae Juss. Byulleten' Moskovskogo Obshchestva Ispytatelei Prirody, Otdel Biologicheskii 97(6):104-107 (in Russian). [Ауферов А.Н. 1992. Типификация некоторых Аальневосточных вилов семейства Ranunculaceae Juss. // Бюлметень МОИП. ОтАел биологический. Т. 97, вып. 6. С. 104-107].

Luferov, A.N. 1995. Thalictrum L. In: Vascular plants of Soviet Far East, vol. 7 (S.S. Kharkevich, ed.), pp. 133-145, Nauka, St. Petersburg (in Russian). [Ауферов A.H. 1995. Thalictrum L. // Сосудистые растения советского Аальнего Востока, т. 7 / под реА. С.С. Харкевича. СПб.: Наука, С. 133-145].

Luferov, A.N. 2004. A taxonomic synopsis of Ranunculaceae of the Far East of Russia. Turczaninowia 7(1):5-84 (in Russian). [Ауферов А.Н. 2004. Таксономический конспект мютиковых (Ranunculaceae) Аальнего Востока России // Turczaninowia. T. 7, №. 1. C. 5-84].

Luferov, A.N. 2015. On some records of Ranunculaceae in the North of Korean Peninsula. Byulleten' Moskovskogo Obshchestva Ispytatelei Prirody, Otdel Biologicheskii 120(3):79 (in Russian). [Ауферов А.Н. 2015. О некоторых находках Ranunculaceae на севере Корейского полуострова // Бюлметень МОИП. ОтАел биологический. Т. 120, вып. 3. С. 79].

Luferov, A.N. 2016. On the distribution of some species of Ranunculaceae in Northeast China. Byulleten' Moskovskogo Obshchestva Ispytatelei Prirody, Otdel Biologicheskii 121(6): 85 (in English \& Russian). [Ауферов А.Н. 2016. О распространении некоторых вилов Ranunculaceae на северовостоке Китая // Бюлметень МОИП. ОтАел биологический. Т. 121, вып. 6. С. 85].

Lysenko, D.S. 2010. Adventive plants. In: Flora and vegetation of Magadan Region (Checklist of vascular plants and the outline of vegetation) (A.N. Berkutenko, ed.), IBPN DVO RAN, Magadan, pp. 235-290 (in Russian). [Аысенко А.C. 2010. Алвентивные растения // ФАора и растительность МагаАанской области (конспект сосудистых растений и очерк растительности) / поА реА. А.Н. Беркутенко. МагаАан: ИБПС АВО РАН. С. 235-290].

Maiorov, S.R, V.D. Bochkin, Yu.A. Nasimovich \& A.V. Scherbakov 2012. Adventive flora of Moscow and the Moscow region. KMK Scientific Press, Moscow, 412 pp. (in Russian). [Майоров С.Р., Бочкин В.А., Насимович Ю.А., Щербаков А.В. 2012. ААвентивная флора Москвы и Московской области. М.: Товарищество научных изданий KMK. 412 c.].

Marcussen, T. \& I. Nordal 1998. Viola suavis, a new species in the Nordic flora, with analyses of the relation to other species in the subsection Viola (Violaceae). Nordic Journal of Botany 18(2):221-237.

Medvedev, P.F. \& A.I. Smetannikova 1981. The forage crops of the European part of the USSR. Kolos, Moscow, 336 pp. (in Russian). [Медведев П.Ф., Сметанникова, А.И. 1981. Кормовые растения европейской части СССР. М.: Колос. 336 с.].

Mitchell, W.M. \& H.J. Hodgson 1968. Hybridization within the Triticea of Alaska. A new $\times$ Elychordeum and comments. Rhodora 70: 467-473.

Munz, P. 1946. Aquilegia: The cultivated and wild columbines. Gentes Herbarum 7(1):1-150.

Murtazaliev, R.A. 2009. Check-list of the flora of Dagestan (Euphorbiaceae-Dipsacaceae), vol.2. Izdatel'skiy dom Epokha, Makhachkala, 248 pp. (in Russian). [Муртазалиев P.A. 2009. Конспект флоры Аагестна (Euphorbiaceae-Dipsacaceae). Махачкала: Издательский дом Эпоха. Т. 2. 248 c.].

Nardi, E. 2016. Il genere Aquilegia L. (Ranunculaceae) in Italia / The genus Aquilegia L. (Ranunculaceae) in Italy. Aquilegiarum Italicarum in Europaearum conspectu description. Universitario Polistampa, Firence, 688 pp.

Nevski, S.A. 1937. Thalictrum L. In: Flora of the USSR, vol. 7 (B.K. Shishkin, ed.), pp. 510-528, Izdatel'stvo AN SSSR, Moscow \& Leningrad (in Russian). [Невский C.A. 1937. Thalictrum L. / / ФАора СССР, т. 7 / пол реА. Б.К. Шишкина. М.-А.: ИзА-во АН СССР. С. 510-528].

Nikitin, V.V. \& M.M. Silantieva 2014. Violas (Viola L., Violaceae) of Altai Territory. Novosti systematiki yysshikh rastenii 38:165-201 (in Russian). [Никитин B.B., Симантьева M.M. Фиалки (Viola L., Violaceae) А^тайского края // Новости систематики высших растений. Т. 38. C. 165-201].

Nikitin, V.V. 1996. Viola L. In: Flora of the Eastern Europe, vol. 9 (N.N. Tzvelev, ed.), pp. 180-206, Mir i semya-95, St. Petersburg (in Russian). [Никитин B.B. 1996. Viola L. // ФАора Восточной Европы, т. 9 / под ред. Н.Н. Цвемева. СПб.: Мир и семья-95. С. 180-206].

Nikitin, V.V. 2014. Viola L. In: Maevskii P.F. Flora of the middle zone of the European part of Russia (V.S. Novikov, V.N. Pavlov, D.D. Sokolov, A.K. Timonin, Yu.E. Alekseev \& C.R. Maiorov, eds), pp. 206-211, KMK Scientific Press, Moscow (in Russian). [Никитин B.B. 2014. Viola L. // Маевский П.Ф. ФАора средней полосы европейской части России / под ред. В.С. Новикова, В.Н. Павлова, А.А. Соколова, А.К. Тимонина, Ю.Е. Алексеева, С.Р. Майорова. М.: Товарищество научных изданий KMK. С. 206-211].

Nobis, M., A. Nowak, A.L. Ebel, A. Nobis, S. Nowak, P.D. Gudkova, A.V. Verkhozina, A.S. Erst, G. Lazarski, M.V. Olonova, R. Piwowarczyk, A.A. Bobrov, I.A. Khrustaleva, V. Plášek, M.M. Silantyeva \& J. ZalewskaGałosz 2015. Contribution to the flora of Asian and European countries: new national and regional vascular plant records, 3. Acta Botanica Gallica 162(2): 103-115.

Nold, R. Columbines: Aquilegia, Paraquilegia and Semiaquilegia. Timber Press, Portland, 2003. 192 pp.

Ohwi, J. 1965. Flora of Japan. Smithsonian Institution, Washington, $1067 \mathrm{pp}$.

Ovchinnikova, S.V. \& O.D. Nikiforova 2016. Keys to identification of genera and species of the family Boraginaceae Juss. in Zabaikalsky Territory. Uchenye Zapiski Zabaikal'skogo Gosudarstvennogo Universiteta 11(1):17-26 (in Russian). [Овчинникова С.В., Никифорова О.А. КАючи Аля опре- 
Аеления родов и видов семейства Boraginaceae Juss. Забайкамьского края / / Ученые записки ЗабГУ. Т. 11, № 1. C. 17-26].

Ovchinnikova, S.V. 1997. Lappula Moench. In: Flora of Siberia, vol. 11 (L.I. Malyschev, ed.), pp. 131-142, Nauka, Novosibirsk (in Russian). [Овчинникова С.B. 1997. Lappula Moench // ФАора Сибири, т. 11 / под реА. А.И. Малышева. Новосибирск: Наука. С. 131-142].

Ovchinnikova, S.V. 2003. The system of the genus Eritrichium (Boragianceae). Botanicheskii Zhurnal 88(7):76-87 (in Russian). [Овчинникова С.В. 2003. Система рода Eritrichium (Boragianceae) / / Ботанический журнал. Т. 88, № 7. C. 76-87].

Ovchinnikova, S.V. 2005. The system of the subtribe Echinosperminae (tribe Eritrichieae, Boraginaceae). Botanicheskii Zhurnal 90(8):1153-1172 (in Russian). [Овчинникова С.В. 2005. Система подтрибы Echinosperminae (триба Eritrichieae, Boraginaceae) // Ботанический журнал. T. 90, № 8. C. 1153-1172].

Ovchinnikova, S.V. 2007. Ultrastructure of fruits in some genera of the tribes Eritrichieae (subtribe Eritrichiinae) and Trigonotideae (Boraginaceae). Botanicheskii Zhurnal 92(2): 228-240 (in Russian). [Овчинникова С.В. 2007. УАьтраскульптура плодов некоторых родов из триб Eritrichieae (подтриб̆ Eritrichïnae) и Trigonotideae (Boraginaceae) // Ботанический журнал. Т. 92, № 2. С. 228-240].

Ovchinnikova, S.V. 2009. The synopsis of the subtribe Echinosperminae Ovczinnikova (Boraginaceae) in the flora of Eurasia. Novosti systematiki vysshikh rastenii 41:209_ 272 (in Russian). [Овчинникова С.В. 2009. Конспект подтрибы Echinosperminae Ovczinnikova (Boraginaceae) флоры Евразии // Новости систематики высших растений. Т. 41. С. 209-272].

Ovchinnikova, S.V. 2011. Conspectus of the subgenus Pseudohackelia of genus Eritrichium (Boraginaceae) species. Rastitel'nyi Mir Asiatskoi Rossii 1:41-54 (in Russian). [Овчинникова C.B. 2011. Конспект видов подрода Pseudobackelia рода Eritrichium (Boraginaceae) Растительный мир Азиатской России. № 1. С. 41-54].

Peshkova, G.A. 1990. Hordeum L. In: Flora of Siberia, vol. 2 (L.I. Malyschev, ed.), pp. 55-58, Nauka, Novosibirsk (in Russian). [Пешкова Г.А. 1990. Hordeum L. / / ФАора Сибири, т. 2 / пол реА. А.И. Малышева. Новосибирск: Наука. С. 55-58].

Podlech, D. \& Sh. Zarre 2013. A taxonomic revision of the genus Astragalus (Leguminosae) in the Old Word, vols 1-3. Naturhistorisches Museum Wien, Vienna, 2439 pp.

Ponomarchuk, G.I. \& K.P. Ulanova 1977. To the study of Far-Eastern species of the genus Thalictrum L. In: Natural flora of the Far East (Biology, Use, Protection), pp. 126-131, DNC AN SSSR, Vladivostok (in Russian). [Пономарчук Г.И., УАанова К.П. 1977. К изучению Аальневосточных видов рода Thalictrum L. // Природная флора Аальнего Востока (биология, использование, охрана). ВАадивосток: АНЦ АН СССР. С. 126-131].

Popov, M.G. 1953. Eritrichium Schrad. ex Gaudin. In: Flora of the USSR, vol. 19 (B.K. Shishkin, ed.), pp. 482-521, Izdatel'stvo AN SSSR, Moscow \& Leningrad (in Russian). [Попов М.Г. 1953. Eritrichium Schrad. ex Gaudin // ФАора СССР, т. 19 / поА реА. Б.К. Шишкина. М.; А.: Иза-во АН СССР. С. 482-521].

Popov, M.G. 1957. Flora of Middle Siberia, vol. 1. Izdatel'stvo AN SSSR, Moscow \& Leningrad, 555 pp. (in Russian). [Попов М.Г. 1957. ФАора средней Сибири, т. 1. М.; А.: ИзА-во АН СССР. 555 с.].
Probatova N.S. 1985. Poaceae Bernh. (Gramineae Juss.). In: Vascular plants of the Soviet Far East, vol. 1 (S.S. Kharkevich, ed.), pp. 89-398, Nauka, Leningrad (in Russian). [Пробатова Н.C. 1985. Poaceae Bernh. (Gramineae Juss.) // Сосудистые растения Советского Аальнего Востока, т. 1. / под реА. С.С. Харкевича. А.: Наука. C. 89-398].

Probatova N.S. 2007. Chromosome numbers in the family Poaseae and their significance for taxonomy, phylogeny, and phytogeography (on the example of grains of the Russian Far East). Komarovskie chteniya 55:9-103 (in Russian). [Пробатова Н.С. 2007. Хромосомные числа в семействе Роасеае и их значение Аля систематики, филогении и фитогеографии (на примере змаков АаАьнего Востока России) // Комаровские чтения. Вып. 55. С. 9-103].

Probatova, N.S., D.A. Krivenko \& V.Yu. Barkalov 2017. Further chromosome studies on the flora of Sakhalin and the Kurils, with additions from adjacent regions of the Russian Far East. Botanica Pacifica 6(2):69-75.

Regel, E. 1861. Uebersicht der Arten der Gattung Thalictrum, welche im Russischen Reiche und den angraezenden Laendern wachsen. Bulletin de la Société Impériale des Naturalistes de Moscou 34(1):14-63 + tabl. I-III.

Rozhevitz R.Yu. 1934. Chlorideae Kunth. In: Flora of the USSR, vol. 2 (R.Yu. Rozhevitz \& B.K. Shishkin, ed.), pp. 284-291, Izdatel'stvo AN SSSR, Moscow \& Leningrad (in Russian). [Рожевиц Р.Ю. 1934. Chlorideae Kunth. // ФАора СССР, т. 2 / пол реА. Р.Ю. Рожевица и Б.К. Шишкина. М.; А.: ИзА-во АН СССР. С. 284-291].

Shu, J.C. 2007. Viola L. In: Flora of China: Clusiaceae through Araliaceae, vol. 13 (W. Zhengyi, P.H. Raven \& H. Deyuan, eds), pp. 74-111, Science Press \& MBG Press, Beijing \& St. Louis.

Shu, M.X. 2010. Medicago L. In: Flora of China: Fabaceae, vol. 10 (W. Zhengyi, P.H. Raven \& H. Deyuan, eds.), pp. 553557, Science Press \& MBG Press, Beijing \& St. Louis.

Silantieva, M.M., A.L. Ebel \& T.V. Ebel 2003. Floristic findings in Altai District (Altaisky Territory). Turczaninowia 6(2):42-50 (in Russian). [Силантьева М.М., Эбель А.А., Эбель Т.В. 2003. Фмористические находки в А^тайском районе А^тайского края // Turczaninowia. T. 6, № 2. C. 42-50].

Starchenko, V.M. \& G.F. Darman 2011. Floristic records in the Amur Region. Botanicheskii Zhurnal 96(1):99-103 (in Russian). [Старченко B.M., Аарман Г.Ф. 2011. ФАористические находки в Амурской области // Ботанический журнал. Т. 96, № 1. С. 99-103].

Sun, B. \& S.M. Phillips 2006. Chloris Swartz. In: Flora of China: Poaceae, vol. 22 (W. Zhengyi, P.H. Raven \& H. Deyuan, eds), pp. 489-490, Science Press \& MBG Press, Beijing \& St Louis.

Tamura, M. 1972. Thalictra of Japan, Kuriles, Sakhalin and Korea. Acta Phytotaxonomica et Geobotanica 15(3):80-88.

The Plant List Version 1.1. 2013. Chloris, Available from: http://www.theplantlist.org/1.1/browse/A/Poaceae/ Chloris/. Last accessed 01.01.2013.

The Plant List Version 1.1. 2013. Elyhordeum, Available from: http:/ / www.theplantlist.org/1.1/browse/A/Poaceae/ Elyhordeum/. Last accessed 01.01.2013.

Tzvelev, N.N. 1988. About some species of plants from the European part of the USSR and from the Far East. Novosti systematiki yysshikh rastenii 24:183-190 (in Russian). [Цве- 
мев Н.Н. 1988. О некоторых видах растений из европейской части СССР и с Аальнего Востока // Новости систематики высших растений. Т. 25. С. 183-190].

Tzvelev, N.N. 1989. Persicaria Mill. In: Vascular plants of the Soviet Far East, vol. 4 (S.S. Kharkevich, ed.), pp. 63-79, Nauka, Leningrad (in Russian). ЦЦвелев Н.H. 1989. Persicaria Mill. // Сосудистые растения советского Аальнего Востока, т. 4 / под реА. С.С. Харкевича. $\Lambda$ : Наука. C. 63-79].

Tzvelev, N.N. 2006. Poaceae Barnhart (Gramineae Juss.) In: Conspectus of the flora of Caucasus, vol. 2 (A.L.Takhtajan, ed.), pp. 248-378, Izdatel'stvo Sankt-Peterburgskogo universiteta, St. Petersburg (in Russian). [Цвелев H.H. 2006 Конспект флоры Кавказа, т. 2 / под. реА. А. $\Lambda$. ТахтаАжяна. СПб.: ИзА-во СПбГУ. С. 248-378].

Valentine, D.H., H. Merxmüller \& A. Schmidt. 1968. Viola L. In: Flora Europaea: Rosaceae to Umbelliferae, vol. 2 (T.G. Tutin, V.H. Heywood, N.A. Burges, D.M. Moore, D.H. Valentine, S.M. Walters \& D.A. Webb, ads.), pp. 270-282, Cambridge University Press, Cambridge.

Vasilyeva, I.M. 1996. The generic system of Aquilegia L. (Ranunculaceae) growing in Russia and adjacent regions. Novosti systematiki vysshikh rastenii 30: 8-28 (in Russian). Васильева И.М. 1996. Система рода Aquilegia L. (Ranunculaceae) флоры России и сопредельных госуАарств // Новости систематики высших растений. T. 30. C. 8-28].

Voroshilov, V.N. 1961. About the flora of Soviet Far East (Addition II). Byulleten' Glavnogo Botanicheskogo Sada 40: 4551 (in Russian). ВВорошилов B.H. 1961. O фморе Coветского Аальнего Востока (Аополнение II) / / Бюлметень ГАавного ботанического саАа. Вып. 40. С. 45-51].

Voroshilov, V.N. 1982. The determinant of plants of the Soviet Far East. Nauka, Moscow, 672 pp. (in Russian). [Ворошилов В.Н. 1982. Определитель растений советского Аальнего Востока. М.: Наука. 672 с.].

Vyltsan, N.F. 1977. Viola L. In: Flora of Krasnoyarsk Territory, vol. 7 (A.V. Polozhii, ed.), pp. 24-30, Izdatel'stvo Tomskogo universiteta, Tomsk (in Russian). Вылцан Н.Ф. Viola L. // ФАора Красноярского края, вып. 7 / под реА. А.В. Положий. Томск: Иза-во Томского унивеситета. C. 24-30].

Walsh, N.G. \& T.J. Entwisle (eds) 1996. Flora of Victoria: Dicotyledons: Winteraceae to Myrtaceae, vol. 3. Melbourne, Vic \& Oxford, Inkata \& Butterworth-Heinemann, 1093 pp.

Yakovlev, G.P., A.K. Sytin \& Yu.R. Roskov 1996. Legumes of Nothern Eurasia: A checklist. Royal Botanic Gardens, Kew, 724 pp.

Yena, A.V. 2012. Spontaneous Flora of the Crimean Peninsula. N. Orianda, Simferopol, 232 pp. (in Russian). [Ена A.B. 2012. Природная флора Крымского полуострова. Симферополь: Н. Оріанаа. 232 с.].

Yuzepchuk, S.V. 1949. Viola L. In: Flora of the USSR, vol. 15 (B.K. Shishkin \& E.G. Bobrov, eds.), pp. 350-479, Izdatel'stvo AN SSSR, Moscow \& Leningrad (in Russian). [Юзепчук C.B. Viola L. // ФАора СССР, т. 15 / поА ред. Б.К. Шишкина и Е.Г. Боброва. М.; А.: ИзА-во AH CСCP. C. 350-479].

Zozulin, G.M. 1984. Astragalus L. In: Flora of the Nizhniy Don (G.M. Zozulin \& V.V. Fedyaeva, eds), pp. 204-210). Izdatel'stvo Rostovskogo universiteta, Rostov-na-Donu (in Russian) [Зозулин Г.M. 1984. Astragalus L. //Ф Аора Нижнего Аона / под ред Г.М. Зозулина, В.В. Федяевой. Ростов-на-Аону: ИзА-во Ростов. ун-та. С. 204-210].

Zuev, V.V. 1996. Viola L. In: Flora of Siberia: Geraniaceae-Cornaceae, vol. 10 (G.A. Peshkova, ed.), pp. 82-101, Nauka, Novosibirsk (in Russian). [Зуев B.B. 1996. Viola L. // ФАора Сибири: Geraniaceae-Cornaceae, т. 10 / поА реА. Г.А. Пешковой. Новосибирск: Наука. С. 82-101].

Zuev, V.V. 2012. Violaceae Batsch. In: Checklist of the flora of Asian Russia: Vascularplants (K.S. Baikov, ed.), pp. 147-151, Izdatel'stvo SO RAN, Novosibirsk (in Russian). [Зуев B.B. 2012. Violaceae Batsch. // Конспект флоры Азиатской России: Сосудистые растения / под реА. К.С. Байкова. Новосибирск: ИзА-во СО РАН. С. 147-151]. 